\title{
The Effects of Nitroxyl (HNO) on $\mathrm{H}_{2} \mathrm{O}_{2}$ Metabolism and Possible Mechanisms of HNO Signaling
}

\author{
Matthew I. Jackson ${ }^{1, \#, ~ H a n n a h ~ F . ~ F i e l d s ~}{ }^{2}$, Timothy S. Lujan ${ }^{2}$, Megan M. Cantrell $^{2}$, Joseph \\ Lin $^{2,{ }^{*}}$, and Jon M. Fukuto ${ }^{3,{ }^{*}}$ \\ ${ }^{1}$ Interdepartmental Program in Molecular Toxicology, UCLA School of Public Health, Los \\ Angeles, CA 90095 \\ ${ }^{2}$ Department of Biology, Sonoma State University, Rohnert Park, CA 94928 \\ ${ }^{3}$ Department of Chemistry, Sonoma State University, Rohnert Park, CA 94928
}

\begin{abstract}
Nitroxyl (HNO) possesses unique and potentially important biological/physiological activity that is currently mechanistically ill-defined. Previous work has shown that the likely biological targets for $\mathrm{HNO}$ are thiol proteins, oxidized metalloproteins (i.e. ferric heme proteins) and, most likely, selenoproteins. Interestingly, these are the same classes of proteins that interact with $\mathrm{H}_{2} \mathrm{O}_{2}$. In fact, these classes of proteins not only react with $\mathrm{H}_{2} \mathrm{O}_{2}$, and thus potentially responsible for the signaling actions of $\mathrm{H}_{2} \mathrm{O}_{2}$, but are also responsible for the degradation of $\mathrm{H}_{2} \mathrm{O}_{2}$. Therefore, it is not unreasonable to speculate that $\mathrm{HNO}$ can affect $\mathrm{H}_{2} \mathrm{O}_{2}$ degradation by interacting with $\mathrm{H}_{2} \mathrm{O}_{2}$ degrading proteins possibly leading to an increase in $\mathrm{H}_{2} \mathrm{O}_{2}$-mediated signaling. Moreover, considering the commonality between $\mathrm{HNO}$ and $\mathrm{H}_{2} \mathrm{O}_{2}$ biological targets, it also seems likely that $\mathrm{HNO}$-mediated signaling can also be due to reactivity at otherwise $\mathrm{H}_{2} \mathrm{O}_{2}$-reactive sites. Herein, it is found that $\mathrm{HNO}$ does indeed inhibit $\mathrm{H}_{2} \mathrm{O}_{2}$ degradation via inhibition of $\mathrm{H}_{2} \mathrm{O}_{2}$-metaboilizing proteins. Also, it is found that in a system known to be regulated by $\mathrm{H}_{2} \mathrm{O}_{2}$ (T cell activation), $\mathrm{HNO}$ behaves similarly to $\mathrm{H}_{2} \mathrm{O}_{2}$, indicating that HNO- and $\mathrm{H}_{2} \mathrm{O}_{2}$-signaling may be similar and/or intimately related.
\end{abstract}

\section{Keywords}

Nitroxyl; hydrogen peroxide; Jurkat cells; CD45; T cell activation; thiol proteins; redox signaling

\section{Introduction}

\begin{abstract}
Nitroxyl (HNO) is one of many nitrogen oxide species with important and potentially useful biological activity. Akin to its redox congener nitric oxide (NO), HNO has significant and unique effects on the cardiovascular system that portends its development as a potential therapeutic species [for example, 1]. However, unlike NO, the mechanisms by which HNO
\end{abstract}

\footnotetext{
(C) 2013 Elsevier Inc. All rights reserved.

*To whom correspondence can be addressed: Joseph Lin, 707664 2931, linj@sonoma.edu or Jon M. Fukuto, 707 664 2187 , fukuto@sonoma.edu.

\#Current address: Grand Forks Human Nutrition Research Center, Agricultural Research Service, United States Department of Agriculture, Grand Forks, North Dakota 58203, USA. matthew.jackson@ars.usda.gov

Publisher's Disclaimer: This is a PDF file of an unedited manuscript that has been accepted for publication. As a service to our customers we are providing this early version of the manuscript. The manuscript will undergo copyediting, typesetting, and review of the resulting proof before it is published in its final citable form. Please note that during the production process errors may be discovered which could affect the content, and all legal disclaimers that apply to the journal pertain.
} 
elicits its effects on the cardiovascular system are only beginning to be understood [for example, 2,3,4,5]. Based on previous reports indicating the propensity for $\mathrm{HNO}$ to react with thiols [6,7], it has been proposed that primary targets for $\mathrm{HNO}$ in biological systems are thiol proteins [for example, 8]. That is, HNO can react with specific thiol proteins leading to reversible and/or irreversible thiol modification [9] with consequent effects on protein activity and physiological function. Significantly, HNO has been reported to be one of the fastest thiol modifying species among all biologically (or pharmacologically) relevant species $[10,11]$, consistent with the idea that HNO biological activity can be due to reaction with thiol proteins.

The biologically relevant chemistry of HNO has been examined and a clear picture of its likely biochemical targets has been described [for example, 12,13]. As mentioned immediately above, HNO reacts readily with thiols/thiol proteins. Surprisingly, HNO does not react readily with water (to form a hydrated, gem-diol species akin to formaldehyde). The selectivity of HNO to react with sulfur nucleophiles as opposed to oxygen nucleophiles is likely due to a lack of electron-pair repulsion in the sulfur adduct compared to that in the oxygen adduct [7]. Consistent with this idea, phosphines (like sulfur, phosphorous is a $3^{\text {rd }}$ row element) are also very reactive towards HNO $[11,14]$. Based on this reasoning, it is expected that $\mathrm{HNO}$ will have an especially high affinity for selenoproteins since the selenium atom in selenocysteine can be much more nucleophilic than the corresponding sulfur atom in cysteine [15] and electron-pair repulsion in the seleno product will be considerably less than that of even the sulfur adduct. HNO is also known to readily react with ferric hemes to form typically stable ferrous nitrosyl complexes (Reaction 1) [6].

$$
\mathrm{Heme}-\mathrm{Fe}^{3+}+\mathrm{HNO} \rightarrow \mathrm{Heme}-\mathrm{Fe}^{2+}-\mathrm{NO}+\mathrm{H}^{+}
$$

Thus, the reactivity profile of HNO predicts that it can modify and possibly inhibit proteins with highly reactive (nucleophilic) cysteines, nucleophilic selenocysteines and ferric heme proteins.

Interestingly, hydrogen peroxide $\left(\mathrm{H}_{2} \mathrm{O}_{2}\right)$ is known to react with the same biological groups/ motifs and proteins containing these functionalities are supposed targets for $\mathrm{H}_{2} \mathrm{O}_{2}$ reactivity. The role of $\mathrm{H}_{2} \mathrm{O}_{2}$ in various signaling pathways has been well established and is thought to be mediated primarily by the oxidation of specific thiols that are activated to react with electrophiles such as $\mathrm{H}_{2} \mathrm{O}_{2}$ [for example, 16]. Therefore, proteins that regulate the metabolism of $\mathrm{H}_{2} \mathrm{O}_{2}$ can have potential effects on many signaling pathways [for example, 17]. The proteins primarily responsible for the degradation of $\mathrm{H}_{2} \mathrm{O}_{2}$ are peroxiredoxins (a family of activated cysteine proteins), glutathione peroxidase (GPx, a selenoprotein) and catalase (a ferric heme protein) [for example, 18]. Therefore, it may be expected that HNO is capable of inhibiting $\mathrm{H}_{2} \mathrm{O}_{2}$ metabolism via selective modification of these proteins directly. Taken altogether, it is clearly possible that the biological actions of $\mathrm{HNO}$ and $\mathrm{H}_{2} \mathrm{O}_{2}$ can be intimately intertwined. That is, $\mathrm{HNO}$ has the potential to elicit biological activity by increasing $\mathrm{H}_{2} \mathrm{O}_{2}$ levels in cells (via inhibition of $\mathrm{H}_{2} \mathrm{O}_{2}$ degrading enzymes) and also directly by interacting with otherwise $\mathrm{H}_{2} \mathrm{O}_{2}$-reactive signaling proteins. Herein are described studies of the effects of $\mathrm{HNO}$ and $\mathrm{H}_{2} \mathrm{O}_{2}$ on purified proteins and in cells. Specifically, we compare of the actions of $\mathrm{H}_{2} \mathrm{O}_{2}$ and $\mathrm{HNO}$ on well-characterized signaling systems within established macrophage and $\mathrm{T}$ cell lines. 


\section{Experimental Methods}

\section{Reagents}

Angeli's Salt (AS) was synthesized according to a previously published procedure [19]. Concentrated stock solutions of AS were made up in $10 \mathrm{mM} \mathrm{NaOH}$ and used immediately. In all cases, the $\mathrm{pH}$ of solutions was checked after addition of aliquots of the stock AS solutions to assure that the basic solution did not alter the experimental $\mathrm{pH}$.

\section{Treatment of purified enzymes and activity assay}

Prior to use, glutathione peroxidase (GPx, Sigma, St. Louis, MO) and glutathione reductase (GSR, Sigma, St. Louis, MO) enzymes purchases in a lyophilized form were dissolved and dialyzed against $50 \mathrm{mM}$ potassium phosphate that had been pretreated with Chelex to remove any thiols present in the commercial product. Dialysis was carried out under anaerobic conditions and was preceded by treatment with $1 \mathrm{mM}$ tris-carboxyethyl phosphine for 30 minutes (Research Products International, Mount Prospect, Il) to assure that the proteins were fully reduced. After dialysis, enzymes were diluted anaerobically to concentrations 100 -fold greater than that used for activity assays. Aerobic treatments were carried out at $37^{\circ} \mathrm{C}$ in a water bath for 20 minutes, while anaerobic treatments were performed at $37^{\circ} \mathrm{C}$ in a temperature controlled glycerol bath inside a glove box (PLAS Labs, Lansing, MI) with ambient equilibrium oxygen content present at $0.03 \mathrm{mg} / \mathrm{L}$ or less as determined using an oxygen meter in the glove box (WTW 197i, College Station, TX, USA). All activity assays were carried out aerobically, and in $1 \mathrm{~mL}$ cuvettes, according to the following references: catalase (CAT) [20], GPx [21], GSR [22]. Control experiments demonstrated that neither thermally decomposed AS nor sodium nitrite, the primary aqueous decomposition co-product of AS (besides HNO), inhibited purified or cellular enzymes at levels where AS did produce inhibition. This indicates that HNO and not an ancillary byproduct of AS decomposition was responsible for enzyme inhibition. To ascertain the reversibility of CAT inhibition, the treated protein was washed on a 30,000 dalton M.W. cutoff centrifugal spin column (Centricon, Millipore, Billerica, MA, USA) twice with Chelex treated $50 \mathrm{mM}$ potassium phosphate.

\section{Cell culture and treatment}

RAW264.7 cells were obtained from ATCC (Manassas, VA, USA) and cultured in DMEM with 20 mM HEPES (HyClone, Logan UT, USA) supplemented with 10\% FBS (HyClone, Logan UT, USA), penicillin, streptomycin, glutamine and $0.1 \mu \mathrm{M}$ selenium (sodium selenite) and utilized until passage 18. It has been demonstrated that common cell culture conditions do not supply sufficient selenium for endogenous GPx activity; specific activity of GPx increased approximately 7 fold after addition of selenite to culture maintenance [23]. Cells were maintained at $37^{\circ} \mathrm{C}$ and $5 \% \mathrm{CO}_{2}$ until $\sim 95 \%$ confluent before passaging and seeding into 6-well plates (for assays involving lysates or supernatants, $3 \times 10^{6}$ cells/well) or 96 well plates (for assays involving whole cells, $2-10 \times 10^{4}$ cells/well). For experiments involving the Amplex Red (AR)/Horseradish peroxidase (HRP) assay, phenol red and FBS free media was employed. Cells were treated with AS in full media or, when noted, in serum free media or PBS containing $20 \mathrm{mM}$ HEPES buffer. Treatments were 20 minutes in length, as the $\mathrm{HNO}$ donor AS has a half life of $\sim 2.5$ minutes at $37^{\circ} \mathrm{C}$ there is no additional benefit to be derived from longer treatments.

Jurkat T cells and Lck deficient T cells (JCaM1) were grown in RPMI 1640 (Cellgro) supplemented with 10\% FBS (JRH Biosciences), penicillin, streptomycin, and glutamine. 


\section{Lysate preparation and cellular enzyme assays with RAW cells}

For cell pellet preparation, cell monolayers were washed and scraped into PBS before pelleting and freezing in liquid nitrogen, and stored at $-80^{\circ} \mathrm{C}$ until analysis. Lysates were obtained by adding a detergent based hypotonic lysis buffer containing chelators and phosphatase inhibitors (75 mM potassium phosphate ( $\mathrm{pH} 7.45$ ), $0.5 \%$ NP-40, $0.1 \%$ TritonX-100, $1 \%$ glycerol, $1 \mathrm{mM}$ EGTA, $1 \mathrm{mM}$ DTPA, $5 \mathrm{mM}$ potassium fluoride), thawing the cells on ice, disruption via pipetting and clearing the lysates by centrifugation at 14,000 $\mathrm{x} \mathrm{g}$ for 10 minutes. Analysis of cell lysates was performed in duplicate, at two different protein concentrations: aliquots used in enzyme assays contained approximately $30 \mu \mathrm{g}$ of protein $(\sim 10 \mu \mathrm{L}$ under our lysis conditions). The lysates were analyzed for enzymatic activity according to the following microplate format assays.

\section{CAT}

Catalase was assayed according to a previously published method adapted to microplate format [24]. Aliquots of cell lysate $(\sim 10 \mu \mathrm{L})$ were added to $27 \mu \mathrm{L}$ of $50 \mathrm{mM}$ potassium phosphate buffer, $\mathrm{pH} 7.45$. A further $37 \mu \mathrm{L}$ of $50 \%$ methanol in the same buffer was added and the plate mixed on an orbital shaker. The reaction was initiated with the addition of 10 $\mu \mathrm{L} 0.3 \%$ hydrogen peroxide, mixed and was allowed to proceed for 20 minutes at room temperature with shaking. Subsequently $18.5 \mu \mathrm{L}$ of $7.8 \mathrm{M} \mathrm{NaOH}$ was added and mixed thoroughly. Next, $37 \mu \mathrm{L}$ of $35 \mathrm{mM}$ Purpald in $0.48 \mathrm{M} \mathrm{HCl}$ was added and allowed to incubate for 20 minutes at room temperature with shaking. After incubation, $18.5 \mu \mathrm{L}$ of 65 $\mathrm{mM} \mathrm{KIO}_{4}$ in $0.48 \mathrm{M} \mathrm{NaOH}$ was added to further color development and the plate mixed. Absorbance at $590 \mathrm{~nm}$ was measured with a microplate spectrophotometer (Emax, Molecular Devices). Results were normalized to protein concentrations in cell lysates.

GPx

Glutathione peroxidase activity was assayed by its coupled reaction with purified glutathione reductase [21]. Aliquots of cell lysate $(\sim 10 \mu \mathrm{L})$ were added to 96 well microplates. A mixture comprised of all reagents excepting peroxide $(80 \mu \mathrm{L}$, see below for final concentrations) was added to the lysate and the plate mixed on an orbital shaker. After 5 minutes tertbutyl hydroperoxide was added $(10 \mu \mathrm{L}, 2 \mathrm{mM})$ to initiate the assay and the loss of NADPH was monitored via fluorescent microplate reader. Rates of loss of NADPH were normalized to protein concentrations in cell lysates. The reagents and final concentrations of reagents present in the assay were: Chelex treated potassium phosphate $\mathrm{pH}$ $7.45(75 \mathrm{mM})$, acetylated bovine serum albumin $(25 \mu \mathrm{g} / \mathrm{ml})$, sodium azide $(1 \mathrm{mM})$, diethylenetriaminepentaacetic acid (DTPA) $(0.5 \mathrm{mM})$, NADPH $(0.2 \mathrm{mM})$, reduced glutathione $(5 \mathrm{mM})$, glutathione reductase (bovine, Sigma; $3 \mathrm{u} / \mathrm{mL})$, hydrogen peroxide $(0.2$ $\mathrm{mL}$ ). The use of t-Butyl hydroperoxide as substrate and the inclusion of azide in assay for GPx ensured that catalase activity was not confounding in the measurement of peroxide consumption.

Glutathione reductase activity was assayed in the same format as for GPx [22]. A master mix $(70 \mu \mathrm{L})$ composed of all reagents listed below except oxidized glutathione was added to aliquots of cell lysate and the plate mixed on an orbital shaker. The reagents and final concentrations of reagents present in the assay were: Chelex treated potassium phosphate $\mathrm{pH}$ $7.45(75 \mathrm{mM})$, acetylated bovine serum albumin $(25 \mu \mathrm{g} / \mathrm{mL})$, DTPA $(0.5 \mathrm{mM})$, NADPH $(0.2$ $\mathrm{mM})$, oxidized glutathione $(5 \mathrm{mM})$, flavin adenine dinucleotide phosphate $(1 \mu \mathrm{M})$. After 5 minutes oxidized glutathione was added $(20 \mu \mathrm{L}, 25 \mathrm{mM})$ to initiate the assay and the loss of NADPH was monitored via at $590 \mathrm{~nm}$ in a microplate fluorimeter. Rates of loss of NADPH were normalized to protein concentrations in cell lysates. 


\section{Cellular $\mathrm{H}_{2} \mathrm{O}_{2}$ consumption}

After AS treatment (see cell culture and treatment conditions, above), the cell monolayers were washed twice with PBS and incubated with phenol red and FBS free media containing $50 \mu \mathrm{M}$ hydrogen peroxide. After 20 minutes of coincubation with peroxide at $37 \mathrm{C}$, a $5 \mu \mathrm{L}$ aliquot of the culture supernatant was added to $100 \mu \mathrm{L}$ HRP $)(0.25 \mathrm{U} / \mathrm{mL}$ and $\mathrm{AR}(120 \mu \mathrm{M})$. After 15 minutes emission was read at $590 \mathrm{~nm}$ in a microplate fluorimeter with excitation at $560 \mathrm{~nm}$. Hydrogen peroxide remaining was calculated according to a standard curve [25].

\section{Cellular $\mathrm{H}_{2} \mathrm{O}_{2}$ production}

The basic methodology was patterned after a previously published procedure [25]. To detect extracellular hydrogen peroxide, the AS treated cell monolayers were washed twice with PBS and incubated in $50 \mu \mathrm{L}$ media containing phorbol myristic acetate (PMA, $800 \mathrm{nM})$ and free of phenol red or FBS for 15 minutes. Finally, $50 \mu \mathrm{L}$ HRP/AR mixture ( $0.5 \mathrm{u}$ HRP, 240 $\mu \mathrm{M}$ AR) was added (final concentrations were same as for the peroxide consumption assay) to the wells to detect PMA stimulated $\mathrm{H}_{2} \mathrm{O}_{2}$ production. After 15 minutes fluorescent emission was determined as above. To detect intracellular reduced dioxygen species, after AS treatment the cell monolayers were washed twice with PBS and incubated with dihydrodichlorofluorescein diacetate $\left(\mathrm{H}_{2} \mathrm{DCFDA}, 20 \mu \mathrm{M}\right)$ in PBS for 20 minutes at $37^{\circ} \mathrm{C}$. Subsequently, PMA was added to a final concentration of $800 \mathrm{nM}$ and a 15 minute incubation was carried out. Finally, excitation at $485 \mathrm{~nm}$ and emission at $530 \mathrm{~nm}$ on a microplate fluorimeter allowed fluorometric determination of dye oxidation. Control experiments determined the optimal number of cells $\left(\sim 3-5 \times 10^{4}\right.$ cells/well). Pre-oxidized dichlorofluorescein diacetate (DCFDA) was used as a control to ensure that loading of dye was indeed occurring under the conditions employed.

\section{Fluorimetric Procedure for Measuring CD45}

Using a procedure adapted from a previously published method [26] CD45 activity from treated cells was measured. Approximately $2-3 \times 10^{6}$ cells/well were used for each assay. Jurkat cells were exposed for $15 \mathrm{~min}$ at $37^{\circ} \mathrm{C}$ to various concentrations of either hydrogen peroxide, AS, or decomposed AS buffered in $5 \mathrm{mM}$ HEPES (pH. 7). Cells were then washed once with ice cold PBS before lysis in lysis buffer (1\% NP40, $25 \mathrm{mM}$ Tris, $150 \mathrm{mM} \mathrm{NaCl}$, with 1X Halt ${ }^{\mathrm{TM}}$ Protease Inhibitor Cocktail (Thermo Scientific)) for $10 \mathrm{~min}$ on ice. Lysates were then pre-cleared at $10,000 \times \mathrm{g}$ for $10 \mathrm{~min}$ and then added to wells (high binding Corning ${ }^{\circledR} 96$ well EIA/RIA plate) coated with an anti-mouse CD45 antibody for $2 \mathrm{~h}$ at 37 ${ }^{\circ} \mathrm{C}$. To coat wells, a goat anti-mouse secondary $(4 \mu \mathrm{g} / \mathrm{ml})$ diluted in $0.1 \mathrm{M}$ carbonate buffer pH. 9.5 was incubated overnight at $4^{\circ} \mathrm{C}$. Wells were then washed $3 \mathrm{x}$ with PBS containing

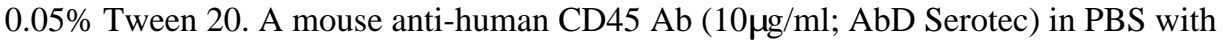
$1 \%$ BSA was added to wells for $2 \mathrm{~h}$ at $37{ }^{\circ} \mathrm{C}$ and then the wells were washed prior to use. To assay CD45 activity, wells were incubated with $30 \mu \mathrm{M}$ fluorescein diphosphate (FDP) in Tris buffer (50 mM Tris- $\left.\mathrm{HCl}, 0.1 \mathrm{mM} \mathrm{CaCl}_{2}, \mathrm{pH} 7.0\right)$ with $50 \mathrm{mM}$ DTT. Phosphatase activity was measured $2 \mathrm{hrs}$ after the addition of FDP on a Synergy HT Multi-Mode Microplate Reader with $485 / 530 \mathrm{~nm}$ filters.

\section{Western blot analysis}

Jurkat cells were rested in RPMI 1640 (Cellgro) buffered with 5mM HEPES for 20 min at $37^{\circ} \mathrm{C}$. Cells were treated and incubated at $37^{\circ} \mathrm{C}$ as indicated in the figure legend and then lysed in lysis buffer (1\% NP40, $150 \mathrm{mM} \mathrm{NaCl}, 50 \mathrm{mM}$ TRIS, 2mM EDTA, with 1X Halt ${ }^{\mathrm{TM}}$ Protease Inhibitor Cocktail (Thermo Scientific)) on ice for $10 \mathrm{~min}$. The lysed cells were then pre-cleared by centrifugation at $10,000 \mathrm{x} \mathrm{g}$ at $4{ }^{\circ} \mathrm{C}$ for 10 minutes prior to analysis. Samples were resolved using SDS-Polyacrylamide Gel Electrophoresis (SDS-PAGE) and transferred to nitrocellulose. The membrane was then blocked using 3\% BSA in TBST, probed with an 
anti-phospho ERK (Cell Signaling Inc.) or anti-total ERK (Cell Signaling Inc.) and visualized using an HRP conjugated secondary and an ECL substrate (Pierce). Images were captured using a Carestream Gel Logic 2200 Pro.

\section{Results}

\section{Nitroxyl inhibits Catalase and Glutathione Peroxidase In vitro}

To begin these studies, we wanted to examine the effect of HNO on purified catalase and glutathione peroxidase, two proteins we hypothesized would be targets of $\mathrm{HNO}$ modification. The effect of $\mathrm{HNO}$ on catalase activity was examined under both aerobic and anaerobic conditions. Since $\mathrm{O}_{2}$ is a product of $\mathrm{H}_{2} \mathrm{O}_{2}$ metabolism by catalase $\left(2 \mathrm{H}_{2} \mathrm{O}_{2} \rightarrow \mathrm{O}_{2}\right.$ $+2 \mathrm{H}_{2} \mathrm{O}$ ), anaerobic conditions could only be maintained during an HNO-catalase preincubation period (20 minutes), followed by an assay of residual activity. For aerobic conditions, the pre-incubation period was done under normal aerobic conditions (bench top). Catalase was found to be dose-dependently inhibited after exposure to $\mathrm{HNO}$ under both anaerobic and aerobic conditions (Figure 1A). The inhibition was greater in the absence of oxygen, possibly due to scavenging of $\mathrm{HNO}$ by $\mathrm{O}_{2}$ or, more likely, oxidative reactivation of the reduced, inhibited enzyme.

Coincident with inhibition, separate incubations under identical conditions provided evidence of spectral changes consistent with conversion of the resting state ferric $\left(\mathrm{Fe}^{3+}\right)$ enzyme to the ferrous-nitrosyl complex $\left(\mathrm{Fe}^{2+}-\mathrm{NO}\right)$, indicative of an overall reduction and nitrosylation of the catalase heme iron moiety (anaerobic conditions; Figure 1B). Isosbestic points were clearly present in the anaerobic condition, but absent in the aerobic condition (not shown), providing mechanistic support for our observation of greater CAT inhibition under anaerobic conditions. The spectrum matched published values [27] and was identical to that obtained by reductive nitrosylation with excess anaerobic nitric oxide (data not shown). Interestingly, the inhibition and nitrosylation of catalase were reversible as demonstrated by the restoration of the activity and $\mathrm{Fe}^{3+}$ spectral characteristics after washing inhibited enzyme on a molecular weight cutoff filter and re-suspension in buffer (data not shown).

The effect of HNO on purified GPx activity was also examined. Exposures were carried out for 20 minutes under either aerobic or anaerobic conditions prior to determination of enzyme activity as it is known that HNO reacts with NADPH, one of the components of the assay system. As shown in Figure 2, glutathione peroxidase is dose-dependently inhibited by HNO under both aerobic and anaerobic conditions. Interestingly, treatment of inhibited GPx with the reductant dithiothreitol (DTT) was able to reverse around 50\% of the inhibition (data not shown) consistent with the idea that some of the inhibition was irreversible. Although there is currently no mechanistic data regarding the mode of inhibition of GPx by HNO, it is likely to be analogous to the well documented thiol reaction with HNO which can have either biologically reversible (disulfide formation) or irreversible (sulfinamide) outcomes (vide infra). In this case, it is proposed that HNO is reacting with the selenocysteine of GPx via similar chemistry. As described in the methods section, GPx activity is monitored using a coupled assay system involving glutathione reductase. Importantly, it was determined that glutathione reductase was not inhibited to any significant extent at submillimolar concentrations of the HNO donor AS (data not shown). Additionally, given the that $>10$ half-lives of AS decomposition had occurred, and that AS treated enzyme solutions were diluted 100 fold prior to GPx activity assay, it is unlikely that inhibition of GSR in the GPx activity assay accounted for observed results. 


\section{Effect of HNO treatment on cells}

To extend these initial in vitro HNO studies, we wanted to examine the effects of HNO on live cells. RAW264.7 macrophages cells were treated with various concentrations of AS and then assayed for GPx activity in cell lysates. HNO treatment resulted in a dose dependent inhibition of GPx (Figure 3). Interestingly, the inhibition was transient as cultures assayed 24 hours after AS treatment exhibited no observable inhibition. This is not necessarily surprising since the half-life of the HNO donor AS under the conditions of these experiments is only approximately 2 minutes; thus cellular thiols may have restored activity to inhibited enzymes, or alternatively, new cellular GPx protein may have been synthesized to supplant inhibited enzyme by the 24 hour time point. Catalase activity in cell lysates was not altered by AS treatment (data not shown). Given that the inhibition of purified catalase by HNO is demonstrably reversible (vide supra), we hypothesize that catalase inhibited during treatment with AS spontaneously reversed under the conditions of cell lysis and lysate preparation. Some evidence for this lies in the observation that anaerobic reaction of purified catalase with HNO produced spectral conversions with clearly delineated isobestic points (Figure 1B), while aerobic reactions were more muddled and did not produce the same magnitude of conversion (not shown).

\section{Nitroxyl inhibits the ability of cells to degrade exogenous and endogenous hydrogen peroxide}

If catalase and GPx are indeed inhibited in cells after treatment with a source of $\mathrm{HNO}$, then the ability of the cell culture to metabolize a challenge dose of $\mathrm{H}_{2} \mathrm{O}_{2}$ should be decreased as a consequence. In order to ascertain whether this is the case in our cell system, RAW264.7 macrophages were treated with increasing amounts of AS for 15 minutes. Cells were then washed and media replaced with PBS containing $50 \mu \mathrm{M} \mathrm{H} \mathrm{H}_{2} \mathrm{O}_{2}$. After 15 minutes, remaining peroxide was measured in the supernatant via the AR/HRP assay. Control cells (not treated with $\mathrm{HNO}$ ) were capable of consuming $280 \mathrm{nM}$ peroxide in the 15 minute incubation with $50 \mathrm{M} \mathrm{H}_{2} \mathrm{O}_{2}$ whereas those treated with $320 \mu \mathrm{M}$ AS were only capable of scavenging 144 $\mathrm{nM}$ peroxide (Figure 4A). Thus, $\mathrm{HNO}$ is capable of inhibiting cell-mediated $\mathrm{H}_{2} \mathrm{O}_{2}$ degradation. Interestingly, when HNO-exposed cells were allowed to recover in full media for one hour their ability to scavenge peroxide was restored to control levels (data not shown). This further supports the contention that inhibition of catalase and GPx are reversible, as seen with purified protein, and supposed for the case of lysates from treated cells.

Next we sought to determine whether the ability of $\mathrm{HNO}$ to increase of $\mathrm{H}_{2} \mathrm{O}_{2}$ levels (presumably via inhibition of $\mathrm{H}_{2} \mathrm{O}_{2}$ degradation pathways) also occurred when $\mathrm{H}_{2} \mathrm{O}_{2}$ was generated endogenously via phorbol ester stimulation. Thus, cells were treated with AS for 15 minutes, and then subsequently stimulated with $800 \mathrm{nM}$ phorbol myristic acetate (PMA) to induce protein kinase $\mathrm{C}$ dependent NADPH oxidase activation and endogenous production of hydrogen peroxide. Extracellular $\mathrm{H}_{2} \mathrm{O}_{2}$ was then measured via the AR/HRP assay. As shown in Figure 4B, increasing amounts of $\mathrm{HNO}$ caused an increase in extracellular $\mathrm{H}_{2} \mathrm{O}_{2}$, presumably due to $\mathrm{HNO}$-mediated inhibition of $\mathrm{H}_{2} \mathrm{O}_{2}$ degradation pathways. Interestingly, in normal cells (no PMA treatment) $\mathrm{HNO}$ did not lead to an increase in extracellular $\mathrm{H}_{2} \mathrm{O}_{2}$. Possible reasons for the lack of $\mathrm{H}_{2} \mathrm{O}_{2}$ increase in cells not treated with PMA are discussed later.

\section{Comparison of cell signaling associated with $\mathrm{HNO}$ and $\mathrm{H}_{2} \mathrm{O}_{2}$}

The role $\mathrm{H}_{2} \mathrm{O}_{2}$ plays in signaling has been well established in many signaling pathways. It is well-documented that the phosphatase $\mathrm{CD} 45$ can be regulated by redox processes associated with interaction with $\mathrm{H}_{2} \mathrm{O}_{2}$ [for example, 28,29]. As a cysteine-based protein tyrosine phosphatase, $\mathrm{CD} 45$ is susceptible to reaction of the reactive cysteine thiolate with $\mathrm{H}_{2} \mathrm{O}_{2}$ 
leading to inhibition of phosphatase activity. In fact, $\mathrm{H}_{2} \mathrm{O}_{2}$-mediated inhibition of $\mathrm{CD} 45$ can be used as an assay for $\mathrm{H}_{2} \mathrm{O}_{2}$ generation in cells [30]. As mentioned previously, a primary site of HNO reactivity in biological systems is reported to be reaction with thiols/thiol proteins. Thus, it may be expected that $\mathrm{H}_{2} \mathrm{O}_{2}$ and $\mathrm{HNO}$ possess similar, if not identical, biological targets and may have similar effects. To examine this, the effect of $\mathrm{H}_{2} \mathrm{O}_{2}$ and $\mathrm{HNO}$ on the activity of CD45 was compared. Jurkat cells were exposed to $\mathrm{H}_{2} \mathrm{O}_{2}(1$ and 5 $\mathrm{mM})$ or the HNO donor AS (1 and $5 \mathrm{mM})$ for 15 minutes at $37^{\circ} \mathrm{C}$ followed by detergentmediated cell lysis. CD45 in the cell lysates was then isolated using an anti-CD45 antibody and phosphatase activity determined using the substrate fluorescein diphosphate (FDP). As shown in Figure 5, both $\mathrm{H}_{2} \mathrm{O}_{2}$ and $\mathrm{HNO}$ exhibited a concentration-dependent inhibition of CD45 activity. It needs to be mentioned that the assay for CD45 requires the presence of extremely high concentrations of dithiothreitol (DTT, $50 \mathrm{mM}$ ). Oxidation of thiols by hydrogen peroxide typically results in sulfenic acid (RSOH) and/or disulfide (RSSR) formation and since DTT will readily reduce sulfenic acids and disulfides back to the corresponding thiols, the inhibition shown in Figure 5 likely represents irreversible modification of the cysteine thiol. That is, intracellular $\mathrm{H}_{2} \mathrm{O}_{2}$-mediated inhibition of CD45 via sulfenic acid or disulfide formation at the active site cysteine will not be detected in this assay. Thus, the inhibition observed at high levels of $\mathrm{H}_{2} \mathrm{O}_{2}(5 \mathrm{mM})$ is most probably due to oxidation of the CD45 cysteine thiol to the sulfinic acid $\left(\mathrm{RSO}_{2} \mathrm{H}\right)$. Significantly, $\mathrm{HNO}$ is known to oxidize thiols to either disulfides or sulfinamides, depending on the nature of the thiol and reaction conditions [9]. Like a sulfinic acid, a sulfinamide product will also not be reversed by DTT, indicating that at least some of the HNO-mediated inhibition of CD45 likely represents thiol conversion to the sulfinamide oxidation state.

\section{Effect of $\mathrm{H}_{2} \mathrm{O}_{2}$ and $\mathrm{HNO}$ on ERK phosphorylation}

It is well established that stimulation of the T-cell receptor (TCR) will result in phosphorylation (activation) of extracellular signal-regulated kinase (ERK) via the RasRaf-Mek-ERK pathway, and that CD45 plays an important role in this activation [for example, 31]. However the role of CD45 in this context is complex. Thus, we simply assayed the phosphorylation status of ERK as a downstream indicator of CD45 activity (albeit indirect and not exclusive). Indeed, $\mathrm{H}_{2} \mathrm{O}_{2}$-mediated increase in ERK phosphorylation via CD45 inhibition has been demonstrated [29]. As shown in Figure 6A, both $\mathrm{H}_{2} \mathrm{O}_{2}$ and $\mathrm{HNO}$ were capable of eliciting significant ERK phosphorylation at $1 \mathrm{mM}$ and $100 \mu \mathrm{M}$ concentrations of either the HNO-donor AS or authentic $\mathrm{H}_{2} \mathrm{O}_{2}$. The time-dependence of $\mathrm{HNO}$ - and $\mathrm{H}_{2} \mathrm{O}_{2}$-mediated (both at $1 \mathrm{mM}$ ) ERK phosphorylation was also examined (Figure 6B). Both $\mathrm{HNO}$ and $\mathrm{H}_{2} \mathrm{O}_{2}$ elicited a fleeting increase in ERK phosphorylation. Interestingly, the peak ERK-phosphorylation for $\mathrm{HNO}$ and $\mathrm{H}_{2} \mathrm{O}_{2}$ were found to be different - 15 minutes for AS and 5 minutes for $\mathrm{H}_{2} \mathrm{O}_{2}$. It should be realized, however, that the half-life for $\mathrm{HNO}$ release from AS under these conditions is approximately 2 minutes. Thus, maximum levels of $\mathrm{HNO}$ from AS decomposition will not be reached immediately as is the case for $\mathrm{H}_{2} \mathrm{O}_{2}$.

\section{Effect of $\mathrm{H}_{2} \mathrm{O}_{2}$ and $\mathrm{HNO}$ on ERK phosphorylation in lymphocyte-specific protein tyrosine kinase (Lck)-deficient cells}

Above (Figure 6), exposure of Jurkat cells to $\mathrm{HNO}$ or $\mathrm{H}_{2} \mathrm{O}_{2}$ - mediated leads to an increase in ERK phosphorylation, presumably via inhibition of CD45. The signal transduction pathway for ERK phosphorylation via inhibition of CD45 in T cells requires the presence of Lck. That is, inhibition of CD45 phosphatase activity leads to increased Lck phosphorylation which, via a series of steps, leads to ERK phosphorylation [for example, 29]. Therefore, it would be expected that Lck-deficient cells would be resistant to the effects of $\mathrm{HNO}$ and $\mathrm{H}_{2} \mathrm{O}_{2}$ on ERK phosphorylation since affects on CD45 would be insulated from the activation (i.e. ERK phosphorylation) pathway. This was found to be the case. As shown in Figure 7, Lck-deficient cells (JCaM1) showed a dramatically decreased level of HNO- or 
$\mathrm{H}_{2} \mathrm{O}_{2}$-dependent ERK phosphorylation compared to wild-type cells, consistent with the idea that the HNO- or $\mathrm{H}_{2} \mathrm{O}_{2}$-mediated increases in ERK phosphorylation were a result of effects on CD45.

\section{Discussion}

Nitroxyl has potentially important and therapeutically useful biological activity [32]. Likewise, $\mathrm{H}_{2} \mathrm{O}_{2}$ has also been reported to possess significant and important biological function as a signaling molecule [for example, 17]. Interestingly, the biological actions of $\mathrm{H}_{2} \mathrm{O}_{2}$ and $\mathrm{HNO}$ have significant overlap. For example, both species are reported to be capable of eliciting hyperpolarization in the vascular system [33,34], affect the $\mathrm{Ca}^{2+}$ levels in cells via regulation of sarcoendoplasmic reticulum $\mathrm{Ca}^{2+}$ ATPase (SERCA) $[5,35,36$,$] and/$ or the ryanodine receptor $[37,38]$. Based on the apparent similarities in the biological activities and chemistry of $\mathrm{H}_{2} \mathrm{O}_{2}$ and $\mathrm{HNO}$, it is intriguing to speculate that the reason for this can be a result of 1) the ability of $\mathrm{HNO}$ to inhibit $\mathrm{H}_{2} \mathrm{O}_{2}$ degradation pathways leading to increased, signaling levels of $\mathrm{H}_{2} \mathrm{O}_{2}$ and/or 2) $\mathrm{HNO}$ interactions with $\mathrm{H}_{2} \mathrm{O}_{2}$ reactive sites leading to similar signaling phenomena. Herein, both possibilities are addressed.

From a purely chemical perspective, it is clear that $\mathrm{HNO}$ has striking similarity to the biological chemistry of $\mathrm{H}_{2} \mathrm{O}_{2}$. For example, like $\mathrm{H}_{2} \mathrm{O}_{2}$, $\mathrm{HNO}$ is an electrophile capable of modifying nucelophilic moieties such as thiol groups. Significantly, both $\mathrm{H}_{2} \mathrm{O}_{2}$ and $\mathrm{HNO}$ are capable of eliciting either biologically reversible or irreversible (or semi-irreversible) thiol modification. In the case of $\mathrm{H}_{2} \mathrm{O}_{2}$, initial oxidation of thiols leads to the generation of a sulfenic acid, which can further oxidize to give a sulfinic acid/sulfinate (Reactions 2 and 3).

$$
\begin{gathered}
\mathrm{H}_{2} \mathrm{O}_{2}+\mathrm{RSH} \rightarrow \mathrm{H}_{2} \mathrm{O}+\mathrm{RSOH} \text { (sulfenic acid) } \\
\mathrm{H}_{2} \mathrm{O}_{2}+\mathrm{RSOH} \rightarrow \mathrm{RS}(\mathrm{O}) \mathrm{OH} / \mathrm{RS}(\mathrm{O}) \mathrm{O}^{-} \text {(sulfinic acid/sulfinate) }
\end{gathered}
$$

Sulfenic acids can also further react with another equivalent of thiol to give a disulfide and water (Reaction 4).

$$
\mathrm{RSOH}+\mathrm{RS}{ }^{\prime} \mathrm{H} \rightarrow \mathrm{H}_{2} \mathrm{O}+\mathrm{RSS} \text { 'R (disulfide) }
$$

Both disulfides and sulfenic acids are readily reduced back to the corresponding thiol in biological systems whereas the $4 \mathrm{e}^{-}$oxidation to the sulfinic acid/sulfinate is considered to be primarily irreversible (although sulfinates have been found to be reversed in peroxiredoxins via the ATP-dependent enzyme sulfiredoxin $[39,40]$ ). The reaction of HNO with thiols can also lead to multiple products with different aptitudes for biological reversibility [9]. HNO can react with a thiol to give initially an N-hydroxysulfenamide (Reaction 5) that can further react with another thiol to give a biologically reversible disulfide product (Reaction 6).

$$
\begin{aligned}
\mathrm{RSH}+\mathrm{HNO} & \rightarrow \mathrm{RSNHOH} \\
\mathrm{RSNHOH}+\mathrm{RSH} & \rightarrow \mathrm{NH}_{2} \mathrm{OH}+\mathrm{RSSR}
\end{aligned}
$$

Alternatively, the intermediate N-hydroxysulfenamide can rearrange to a sulfinamide (Reaction 7). 
Significantly, the reaction of $\mathrm{HNO}$ with a thiol to give a sulfinamide (the combination of Reactions 5 and 7) represents a direct, $4 \mathrm{e}^{-}$oxidation of a thiol, a process that requires two steps and two equivalents of $\mathrm{H}_{2} \mathrm{O}_{2}$. The sulfinamide product from Reaction 7 can be reduced back to the corresponding thiol by excess thiols [41] but is considerably slower than disulfide reduction. Thus, although a sulfinamide can, in theory, be reduced back to the thiol under biological systems, its lifetime is likely to be significantly greater compared to other oxidized thiol species such as disulfides and sulfenic acids.

Thiols/thiolates are not the only biological nucleophile capable of reacting with $\mathrm{H}_{2} \mathrm{O}_{2}$ or, presumably, HNO. Indeed, it is well-established that the highly nucleophilic and redox active selenoproteins (containing a selenocysteine) can readily react with $\mathrm{H}_{2} \mathrm{O}_{2}$. For example, the selenoprotein glutathione peroxidase readily reacts with both hydrogen peroxide and alkylhydroperoxides during the catalysis of peroxide degradation. Although it has not been unequivocally demonstrated that HNO reacts with selenoproteins, it appears highly likely that this would be the case.

Both $\mathrm{HNO}$ and $\mathrm{H}_{2} \mathrm{O}_{2}$ also react readily with ferric and ferrous heme proteins. In the case of $\mathrm{HNO}$, coordination complexes can be generated that can inhibit the activity of the iron heme protein. In the case of $\mathrm{H}_{2} \mathrm{O}_{2}$, reaction with metalloproteins, such as catalase, typically leads to its degradation.

All of the chemistry discussed immediately above indicates that HNO should be capable of interacting with biological sites of $\mathrm{H}_{2} \mathrm{O}_{2}$ reactivity regardless of whether these sites are responsible for $\mathrm{H}_{2} \mathrm{O}_{2}$ degradation or signaling. Importantly, $\mathrm{HNO}$ and $\mathrm{H}_{2} \mathrm{O}_{2}$ also have similar molecular dimensions, indicating that $\mathrm{HNO}$ should have physical access to sites with $\mathrm{H}_{2} \mathrm{O}_{2}$ reactivity. Thus, $\mathrm{HNO}$ should affect both the degradation of $\mathrm{H}_{2} \mathrm{O}_{2}$ and, possibly, interact at reactive sites normally associated with $\mathrm{H}_{2} \mathrm{O}_{2}$ signaling. In this study, we have found that, generally, this is true. In vitro, $\mathrm{HNO}$ is able to inhibit the purified catalase (Figure 1A) via the generation of the ferrous nitrosyl species (Figure 1B). Interestingly, the inhibition of catalase was fleeting as the ferrous-nitrosyl adduct spontaneously reverted to the active ferric enzyme when $\mathrm{HNO}$ was no longer present. Although $\mathrm{HNO}$ is known to react with catalase with a reasonably high rate constant $\left(10^{6} \mathrm{M}^{-1} \mathrm{~s}^{-1}[10]\right)$, the ferrous nitrosyl adduct appears to be unstable with respect to regeneration of the ferric enzyme.

Nitroxyl is also able to inhibit purified GPx (Figure 2) as well as the glutathione peroxidase of HNO-treated cells (Figure 3). The inhibition of GPx by HNO was determined not to be due to the inhibition of GSH reductase under the conditions of these experiments. It is not surprising that $\mathrm{HNO}$ would react readily with the selenoprotein GPx due to the known propensity of $\mathrm{HNO}$ to react with sulfur (and its lack of reactivity with, for example, water). That is, HNO appears to react readily with larger, "softer" nucleophiles (i.e. thiols, phosphines, selenides, etc.) [11,42]. The mechanism of inhibition of GPx by HNO is proposed to occur via rapid reaction with the reactive selenocysteine in the active site (the $\mathrm{H}_{2} \mathrm{O}_{2}$ reactive site). To be sure, the fate of an HNO-selenide adduct has not been examined. However, it can be proposed that it has the potential to act similarly to the established reaction of $\mathrm{HNO}$ with thiols (Figure 8A) [9] leading to either the selenosulfide or seleninamide product. Importantly, the generation of a selenosulfide is a normal part of the catalytic cycle of GPx [43], indicating that this species can be easily converted back to the active selenide in biological systems. However, the possible generation of the seleninamide product may represent a novel pathway that is not part of the normal catalytic cycle. In the case of the reaction of $\mathrm{HNO}$ with thiols (Figure 8A), sulfinamide formation is thought to 
represent a biologically irreversible (or at best very slowly reversible) path. Whether seleninamide formation is a non- or slowly-reversible pathway (akin to sulfinamide formation) remains to be determined (and currently under investigation in this laboratory). However, based on the analogous thiol system, it may be expected that the kinetics of biological reversal of the seleninamide will be very different from selenosulfide reversal. In this study, it was found that the inhibition of GPx by HNO is stable to extended experimental manipulation (i.e. treatment of cells with HNO followed by cell lysis and analysis of GPx activity in the cell lysate showed inhibition of GPx, Figure 3), but possibly reversible by thiols in vitro and in cells. Together these results indicate that GPx inhibition may be due to partially irreversible or slowly-reversible HNO-mediated modification of the active site selenocysteine of GPx or possible irreversible modification of cysteine residues on GPx.

As stated earlier, peroxiredoxins (which are activated cysteine proteins) represent another significant $\mathrm{H}_{2} \mathrm{O}_{2}$ degrading family of proteins. Herein, the effect of $\mathrm{HNO}$ on peroxiredoxin activity was not specifically examined. However, $\mathrm{HNO}$ was shown to inhibit the overall ability of cultured macrophages to degrade $\mathrm{H}_{2} \mathrm{O}_{2}$ (derived from PMA treatment) (Figure 4), consistent with the idea that proteins (at the very least catalase and GPx) are being affected by $\mathrm{HNO}$, leading to an overall decrease in the ability of the cell to degrade $\mathrm{H}_{2} \mathrm{O}_{2}$. Thus, $\mathrm{HNO}$ appears to be capable of altering $\mathrm{H}_{2} \mathrm{O}_{2}$ levels in cells, possibly leading to an increase in $\mathrm{H}_{2} \mathrm{O}_{2}$-mediated signaling. Interestingly, treatment of cells with $\mathrm{HNO}$ alone (i.e. no PMA) did not lead to an increase in extracellular $\mathrm{H}_{2} \mathrm{O}_{2}$. It is likely that $\mathrm{HNO}$ was able to inhibit $\mathrm{H}_{2} \mathrm{O}_{2}$ degradation pathways in both cases (with and without PMA treatment), but only in the case of PMA stimulated $\mathrm{H}_{2} \mathrm{O}_{2}$ generation was the level of $\mathrm{H}_{2} \mathrm{O}_{2}$ high enough to overcome the lowered activity of the $\mathrm{H}_{2} \mathrm{O}_{2}$-degradation pathways (allowing higher measureable $\mathrm{H}_{2} \mathrm{O}_{2}$ levels).

For the purposes of testing the idea that $\mathrm{HNO}$ and $\mathrm{H}_{2} \mathrm{O}_{2}$ can have similar biological targets/ activities, T cell activation via inhibition of the protein tyrosine phosphatase CD45 was examined. It should be stressed that these studies are not attempting to examine physiologic/ pharmacologic effects within T cell signaling pathways, rather CD45 is simply being used as a one of many potential targets for $\mathrm{HNO}$ and $\mathrm{H}_{2} \mathrm{O}_{2}$. It has been reported that CD45, a cysteine-based tyrosine phosphatase, can be inhibited by $\mathrm{H}_{2} \mathrm{O}_{2}$ [for example, 30], leading to $\mathrm{T}$ cell activation [29]. Full activation of Lck, an important and early step in T cell activation, occurs when the tyrosine residue 394 (Tyr-394) is phosphorylated. Since dephosphorylation of Tyr-394 by CD45 leads to inactivation of Lck, inhibition of CD45 phosphatase activity results in Lck activation and $\mathrm{T}$ cell activation. Lck activation results in a cascade of events that ultimately leads to ERK phosphorylation, among other events. A simplified scheme of the relationship between CD45, Lck and T cell activation is shown in Figure 9. It needs to be mentioned that Figure 9 is highly simplified and only shows the interaction of CD45 with Tyr-394 of Lck. It is known that CD45 can also dephosphorylate the negative regulatory site Tyr-505 of Lck and phosphorylation of this residue inhibits Lck activity [44]. Thus, in theory, CD45 inhibition may also be able to decrease Lck activity because of increased levels of Tyr505 phosphorylation. However, it appears that the predominant effect of CD45 inhibition is to activate Lck via increases in Tyr-394 phosphorylation $[45,46]$.

Herein is demonstrated that $\mathrm{HNO}$ and $\mathrm{H}_{2} \mathrm{O}_{2}$ behave similarly with respect to inhibition of CD45 activity. Treatment of Jurkat cells with either $\mathrm{H}_{2} \mathrm{O}_{2}$ or the HNO-donor AS at concentrations of $1-5 \mathrm{mM}$ for 15 minutes resulted in significant decreases in the activity of isolated enzyme from these cells. It should be noted that HNO levels generated by AS (and other donors as well) are typically much lower (as much as $1 / 100^{\text {th }}$ ) of the concentrations of AS applied [47]. Thus, even at the $5 \mathrm{mM}$ level of AS employed in the Jurkat cell experiments, HNO levels never rise above $50 \mu \mathrm{M}$ and rapidly drop off due to the short half- 
life of AS. Although a precise quantitative comparison of the potency of $\mathrm{HNO}$ versus $\mathrm{H}_{2} \mathrm{O}_{2}$ remains difficult due to imprecisely known and rapidly changing $\mathrm{HNO}$ levels, it is clear that $\mathrm{HNO}$ is significantly more potent than $\mathrm{H}_{2} \mathrm{O}_{2}$ in affecting CD45 activity. Observed inhibition for both oxidants represents an irreversible modification of CD45 since the assay conditions for enzyme activity contained $50 \mathrm{mM}$ DTT. It appears likely that the observed $\mathrm{H}_{2} \mathrm{O}_{2}$ mediated inhibition is the result of sulfinate formation (Reactions 2 and 3) and HNOmediated inhibition is due to the formation of a sulfinamide formation (Reactions 5 and 7 ) at the active site cysteine thiol. Moreover, examination of downstream ERK phosphorylation is consistent with the observation that $\mathrm{H}_{2} \mathrm{O}_{2}$ and $\mathrm{HNO}$ inhibit CD45 activity. Both $\mathrm{HNO}$ and $\mathrm{H}_{2} \mathrm{O}_{2}$ treatment of Jurkat cells followed by Western blot analysis shows the expected increase in ERK phosphorylation, presumably due in part to CD45 inactivation. Of course, the observed increase in ERK phosphorylation could be the result of $\mathrm{H}_{2} \mathrm{O}_{2}$ - or $\mathrm{HNO}$ mediated inhibition of other phosphatases as well (i.e. a phosphatase that dephosphorylates ERK). Since Lck is a crucial component in this pathway (Figure 9), the absence of Lck should lead to an uncoupling of CD45 inhibition and ERK phosphorylation. This was found to be the case as Lck-deficient cells do not exhibit increases in ERK phosphorylation when treated with $\mathrm{H}_{2} \mathrm{O}_{2}$ or $\mathrm{HNO}$ (Figure 7). This observation is consistent with the signaling protein relationships shown in Figure 9, but not an unequivocal demonstration of the direct relationship between CD45 inhibition and increased Lck phosphorylation. However, previous reports have definitely correlated CD45 inhibition by $\mathrm{H}_{2} \mathrm{O}_{2}$ with increased LckTyr-394 phosphorylation [29]. Moreover, Nyakeriga and coworkers have demonstrated that $\mathrm{H}_{2} \mathrm{O}_{2}$ exposure also leads to increased Lck Tyr-394 phosphorylation [48]. Finally, the fact that phosphorylated Tyr-394 of Lck is a substrate for CD45 is well established [for example, 44]. Thus, strong correlations between $\mathrm{CD} 45$ inactivation by $\mathrm{H}_{2} \mathrm{O}_{2}$ and increased Lck Tyr-394 phosphorylation are present in the literature. It is also important to note that CD45defiicent Jurkat cells have been previously reported to still induce significant global tyrosine phosphorylation upon $\mathrm{H}_{2} \mathrm{O}_{2}$ stimulation [49]. Therefore $\mathrm{CD} 45$ is presumably not the only site of action of $\mathrm{H}_{2} \mathrm{O}_{2}$ and $\mathrm{HNO}$ in the T cell activation pathway leading to ERK phosphorylation, rather it is one of many.

The finding that CD45 requires such high levels of the strong reducing agent DTT in the enzyme assay is curious and indicates that CD45 itself is highly reducing. Indeed, the requirement for $50 \mathrm{mM}$ DTT in the activity assay represents non-physiological, absurdly high levels of reductant and predicts that CD45 would be primarily oxidized under normal physiological conditions. Whether this is the case or not remains to be determined.

It is worth mentioning that $\mathrm{HNO}$ is not the only nitrogen oxide that can affect the T cell activation pathway. Several previous reports indicate that NO can elicit ERK activation in Jurkat cells $[50,51]$. Considering the fact that HNO can be oxidized to NO under biological conditions [for example, 52], a component of the observed effects of HNO could be a result of conversion to NO. However, it is also worth mentioning that thiol modification by HNO is much more facile than that of $\mathrm{NO}$ (as well as chemically distinct), and it is very likely that the majority of the effects observed herein are due to HNO. This statement is supported by the fact that much of the inhibition of, for example, CD45 is irreversible, an observation that is predictable from known $\mathrm{HNO}$ chemistry and less unlikely from known NO chemistry [9].

Due to the fact that both $\mathrm{HNO}$ and $\mathrm{H}_{2} \mathrm{O}_{2}$ are established thiol modifying agents, there is the possibility that both can also have effects on intracellular glutathione levels. Past work from our laboratory indicates that HNO at low levels does not lower GSH levels appreciably, but at higher levels, GSH levels can be diminished [53]. Thus, at the high concentrations of $\mathrm{HNO}$ used in our studies, it is very possible that GSH levels can be depleted leading to a decrease in $\mathrm{H}_{2} \mathrm{O}_{2}$ handling. Significantly, $\mathrm{H}_{2} \mathrm{O}_{2}$ is also known to deplete $\mathrm{GSH}$ levels in cells 
[for example, 54], further illustrating the similarity between $\mathrm{H}_{2} \mathrm{O}_{2}$ and $\mathrm{HNO}$ biological activity.

The results discussed herein support the idea of a possible strong and close relationship between the chemical biology of $\mathrm{H}_{2} \mathrm{O}_{2}$ and $\mathrm{HNO}$. This is not necessarily a new idea since both $\mathrm{HNO}$ and $\mathrm{H}_{2} \mathrm{O}_{2}$ have established reactivity with thiols and thiol proteins [for example, 13,16]. This work demonstrates that $\mathrm{HNO}$ can increase cellular levels of $\mathrm{H}_{2} \mathrm{O}_{2}$ by inhibiting degradation pathways. Whether $\mathrm{HNO}$ is also capable of eliciting an increase in $\mathrm{H}_{2} \mathrm{O}_{2}$ production as well is not known. More important, however, is the finding that $\mathrm{HNO}$ and $\mathrm{H}_{2} \mathrm{O}_{2}$ behave similarly in a pathway known to be regulated by $\mathrm{H}_{2} \mathrm{O}_{2}$ (T cell activation). It is not yet clear whether the ability of $\mathrm{HNO}$ to mimic the signaling of $\mathrm{H}_{2} \mathrm{O}_{2}$ is by causing an increase in $\mathrm{H}_{2} \mathrm{O}_{2}$ levels or by chemically modifying the same sites (thiols) on proteins such as CD45. Considering the known facility by which HNO reacts with thiols [10,11], it seems probable that much of the observed effects of $\mathrm{HNO}$ on otherwise $\mathrm{H}_{2} \mathrm{O}_{2}$-regulated signaling systems would be a result of direct reaction at $\mathrm{H}_{2} \mathrm{O}_{2}$-reactive sites. Consistent with the idea that $\mathrm{HNO}$ is reacting directly at otherwise $\mathrm{H}_{2} \mathrm{O}_{2}$-reactive sites is the finding that $\mathrm{HNO}$ treatment of Jurkat cells elicits a more significant irreversible inhibition of CD45 activity compared to $\mathrm{H}_{2} \mathrm{O}_{2}$ (Figure 5). To be sure, this is a difficult comparison since $\mathrm{HNO}$ is administered via a donor species (AS) and $\mathrm{H}_{2} \mathrm{O}_{2}$ is administered directly, thus the actual concentrations of the effector species are not comparable (vide supra). However, it is unlikely that an $\mathrm{HNO}$-mediated increase in cellular $\mathrm{H}_{2} \mathrm{O}_{2}$ levels would have a greater effect than the extremely high concentrations of $\mathrm{H}_{2} \mathrm{O}_{2}(1-5 \mathrm{mM})$ used in this study. Regardless, this study presents the idea that $\mathrm{HNO}$ and $\mathrm{H}_{2} \mathrm{O}_{2}$ can have overlapping, if not highly analogous, effects on signaling pathways. Since HNO has yet to be established as an endogenously generated signaling species (akin to NO), its possible role as an endogenous signaling species with actions similar to $\mathrm{H}_{2} \mathrm{O}_{2}$ await this determination. However, the pharmacological utility of $\mathrm{HNO}$ is of significant interest [for example, 55] and the mechanistic intricacies of its actions remain an important topic.

\section{Acknowledgments}

The authors are indebted to Dr. Arthur Weiss for the generous donation of numerous reagents and biologicals. This work was supported in part by the National Institutes of Health (HL106598) and the National Science Foundation (CHE-1148641).

\section{Abbreviations}

$\begin{array}{ll}\text { GPx } & \text { Glutathione peroxidase } \\ \text { GSR } & \text { glutathione reductase } \\ \text { AS } & \text { Angeli's salt } \\ \text { CAT } & \text { catalase } \\ \text { DTPA } & \text { diethylenetriaminepentaacetic acid } \\ \text { PMA } & \text { phorbol myristic acetate } \\ \text { DCFDA } & \text { dichlorofluorescein diacetate } \\ \text { DTT } & \text { dithiothreitol } \\ \text { ERK } & \text { extracellular signal-regulated kinase } \\ \text { FDP } & \text { fluorescein diphosphate } \\ \text { HRP } & \text { horseradish peroxidase }\end{array}$


amplex red

\section{References}

1. Feelisch M. Proc Natl Acad Sci, USA. 2003; 100:4978-4980. [PubMed: 12704227]

2. Paolocci N, Katori T, Champion HC, St John ME, Miranda KM, Fukuto JM, Wink DA, Kass DA. Proc Natl Acad Sci, USA. 2003; 100:5537-5542. [PubMed: 12704230]

3. Cheong E, Tumbev V, Abramson J, Salama G, Stoyanovsky DA. Cell Calcium. 2005; 37:87-96. [PubMed: 15541467]

4. Tocchetti CG, Wang W, Froehlich JP, Huke S, Aon MA, Wilson GM, Di Bennedetto G, O'Rourke B, Gao WD, Wink DA, Toscano JP, Zaccolo M, Bers DM, Valdiva HH, Cheng H, Kass DA, Paolocci N. Circ Res. 2007; 100:96-104. [PubMed: 17138943]

5. Lancel S, Zhang J, Evangelista A, Trucillo MP, Tong XY, Siwik DA, Cohen RA, Colucci WS. Circ Res. 2009; 104:720-723. [PubMed: 19265039]

6. Doyle MP, Mahapatro SN, Broene RD, Guy JK. J Am Chem Soc. 1988; 110:593-599.

7. Bartberger MD, Fukuto JM, Houk KN. Proc Natl Acad Sci, USA. 2001; 98:2194-2198. [PubMed: 11226215]

8. Fukuto JM, Carrington SJ. Antiox Redox Signal. 2011; 14(9):1649-1657.

9. Wong PSY, Hyun J, Fukuto JM, Shiroda FN, DeMaster EG, Nagasawa HT. Biochemistry. 1998; 37(16):5362-5371. [PubMed: 9548918]

10. Miranda KM, Paolocci N, Katori T, Thomas DD, Ford E, Bartberger MD, Espey MG, Kass DA, Feelisch M, Fukuto JM, Wink DA. Proc Natl Acad Sci, USA. 2003; 100(16):9196-9201. [PubMed: 12865500]

11. Jackson MI, Han TH, Serbulea L, Dutton A, Ford E, Miranda KM, Houk KN, Wink DA, Fukuto JM. Free Radic Biol Med. 2009; 47:1130-1139. [PubMed: 19577638]

12. Miranda KM. Coord Chem Rev. 2005; 249:433-455.

13. Fukuto JM, Bartberger MD, Dutton AS, Paolocci N, Wink DA, Houk KN. Chem Res Toxicol. 2005; 18:790-801. [PubMed: 15892572]

14. Reisz JA, Zink CN, King SB. J Am Chem Soc. 2011; 133:11675-11685. [PubMed: 21699183]

15. Nauser T, Steinman D, Koppenol WH. Amino Acids. 2012; 42:39-44. [PubMed: 20461421]

16. Forman HJ, Torres M, Fukuto JM. Mol Cell Biochem. 2002; 234/235:49-62. [PubMed: 12162460]

17. Gough DR, Cotter TG. Cell Death and Disease. 2011; 2:e213. [PubMed: 21975295]

18. Rhee SG, Yang KS, Kang SW, Woo HA, Chang TS. Antioxid Redox Signal. 2005; 7:619-626. [PubMed: 15890005]

19. Smith PAS, Hein GH. J Am Chem Soc. 1960; 82:5731-5740.

20. Chance B, Maehly AC. Methods in Enzymology. 1954; 1:764-775.

21. Flohe L, Gunzler WA. Methods in Enzymology. 1984; 105:114-120. [PubMed: 6727659]

22. Carlberg I, Mannervik B. Methods in Enzymology. 1985; 113:484-490. [PubMed: 3003504]

23. Leist M, Raab B, Maurer S, Rosick U, Brigelius-Flohe R. Free Radic Biol and Med. 1996; 21:297306. [PubMed: 8855440]

24. Johansson LH, Hakan Borg LA. Analyt Biochem. 1988; 174:331-336. [PubMed: 3064653]

25. Zhou M, Diwu Z, Panchuk-Voloshina N, Haugland RP. Analyt Biochem. 1997; 253:162-168. [PubMed: 9367498]

26. Rider DA, Young SP. J Immunol Meth. 2003; 277:127-134.

27. Huang J, Kim-Shapiro DB, King SB. J Med Chem. 2004; 47:3495-3501. [PubMed: 15214777]

28. Jin YJ, Friedman J, Burakoff SJ. J Immunol. 1998; 161:1743-1750. [PubMed: 9712039]

29. Lee K, Esselman WJ. Free Radic Biol Med. 2002; 33:1121-1132. [PubMed: 12374624]

30. Kuban-Jankowska A, Knap N, Gorska M, Popowska U, Wozniak M. Biochem Biophys Res Commun. 2011; 415:270-273. [PubMed: 22037457] 
31. Kawauchi K, Lazarus AH, Sanghera JS, Man GLP, Pelech SL, Delovitch TL. Mol Immunol. 1996; 33:287-296. [PubMed: 8649450]

32. Paolocci N, Jackson MI, Lopez BE, Miranda K, Tochetti CG, Wink DA, Hobbs AJ, Fukuto JM. Pharmacol Therapeut. 2007; 113:442-458.

33. Matoba T, Shimokawa H. J Pharmacol Sci. 2003; 92:1-6. [PubMed: 12832848]

34. Andrews KL, Irvine JC, Tare M, Apostolopoulos J, Favaloro JL, Triggle CR, Kemp-Harper BK. Br J Pharmacol. 2009; 157:540-550. [PubMed: 19338582]

35. Redondo PC, Salido GM, Rosado JA, Pariente JA. Biochem Pharmacol. 2004; 67:491-502. [PubMed: 15037201]

36. Froehlich JP, Mahaney JE, Keceli G, Pavlos CM, Goldstein R, Redwood AJ, Sumbilla C, Lee DI, Tocchetti CG, Kass DA, Paolocci N, Toscano JP. Biochemistry. 2008; 47:13150-13152. [PubMed: 19053265]

37. Han H, Weu R, Lai AF, Yin C. Acta Pharm Sin. 2006; 27:888-894.

38. Cheong E, Tumbev V, Abramson J, Salama G, Stoyanovsky DA. Cell Calcium. 2005; 37:87-96. [PubMed: 15541467]

39. Biteau B, Labarre J, Toledano MB. Nature. 2003; 425:980-984. [PubMed: 14586471]

40. Woo HA, Jeong W, Chang TS, Park KJ, Park SJ, Yang JS, Rhee SG. J Biol Chem. 2004; 280:3125-3128. [PubMed: 15590625]

41. Keceli G, Toscano JP. Biochemistry. 2012; 51:4206-4216. [PubMed: 22571165]

42. Bartberger MD, Liu W, Ford E, Miranda KM, Switzer C, Fukuto JM, Farmer PJ, Wink DA, Houk KN. Proc Natl Acad Sci, USA. 2002; 99:10958-10963. [PubMed: 12177417]

43. Lu J, Holmgren A. Selenoproteins. J Biol Chem. 2009; 284:723-727. [PubMed: 18757362]

44. Palacios EH, Weiss A. Oncogene. 2004; 23:7990-8000. [PubMed: 15489916]

45. Saunders AE, Johnson P. Cell Signal. 2010; 22:339-348. [PubMed: 19861160]

46. Lefebvre DC, Felberg J, Cross JL, Johnson P. Biochim Biophys Acta. 2003; 1650:40-49. [PubMed: 12922168]

47. Fukuto JM, Jackson MI, Kaludercic N, Paolocci N. Meth Enzymol. 2008; 440:411-431. [PubMed: 18423233]

48. Nyakeriga AM, Garg H, Joshi A. Cytometry Part A. 2012; 81A:797-805.

49. Jin YJ, Friedman J, Burakoff SJ. J Immunol. 1998; 161:1743-1750. [PubMed: 9712039]

50. Lander HM, Jacovina AT, Davis RJ, Tauras JM. J Biol Chem, 1996. 1996; 271:19705-19709.

51. Deora AA, Hajjar DP, Lander HM. Biochemistry. 2000; 39:9901-9908. [PubMed: 10933809]

52. Fukuto JM, Bartberger MD, Dutton AS, Paolocci N, Wink DA, Houk KN. Chem Res Toxicol. 2005; 18:790-801. [PubMed: 15892572]

53. Lopez BE, Rodriguez CE, Pribadi M, Cook N, Shinyashiki M, Fukuto JM. Arch Biochem Biophys. 2005; 442:140-148. [PubMed: 16139238]

54. Towell JF III, Wang RIH. Biochem Pharmacol. 1987; 36:2087-2093. [PubMed: 3038114]

55. Irvine JC, Ritchie RH, Favaloro JL, Andrews KL, Widdop RE, Kemp-Harper BK. Trends Pharmacol Sci. 2008; 29:601-608. [PubMed: 18835046] 


\section{Highlights}

HNO inhibits $\mathrm{H}_{2} \mathrm{O}_{2}$ degradation processes leading to increased cellular $\mathrm{H}_{2} \mathrm{O}_{2}$ levels. Increased $\mathrm{H}_{2} \mathrm{O}_{2}$ levels associated with $\mathrm{HNO}$ exposure can be, in part, responsible for the signaling actions of $\mathrm{HNO}$.

As chemistry would predict, $\mathrm{HNO}$ reacts at otherwise $\mathrm{H}_{2} \mathrm{O}_{2}$-reactive sites leading to analogous signaling.

The effect of $\mathrm{HNO}$ on $\mathrm{T}$ cell signaling is analogous to the established signaling associated with $\mathrm{H}_{2} \mathrm{O}_{2}$.

Both $\mathrm{HNO}$ and $\mathrm{H}_{2} \mathrm{O}_{2}$ have the same general ability to inhibit the activity of the cysteine phosphatase CD45. 
A

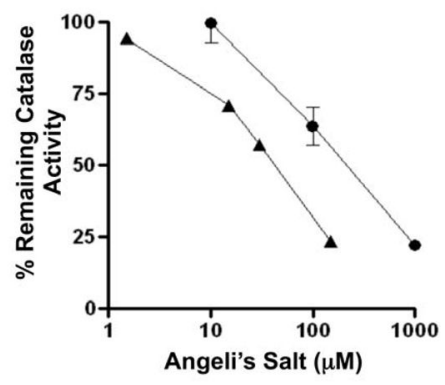

B

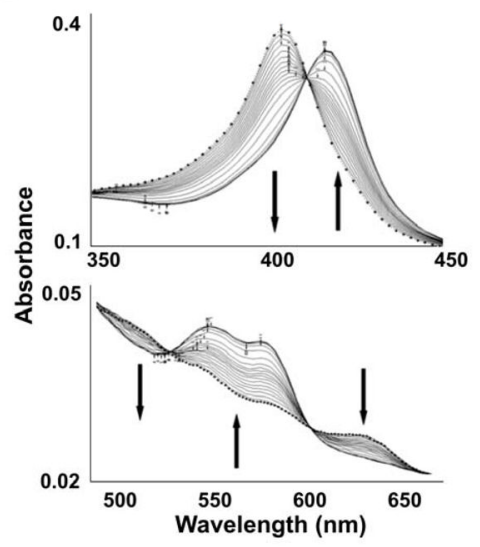

Figure 1.

(A) Inhibition of catalase by HNO (via the HNO-donor Angeli's salt) under aerobic ( and anaerobic $(\boldsymbol{\Delta})$ conditions. Symbols indicate means \pm standard deviation, error bars are sometimes smaller than the means symbol. Above $12.5 \mu \mathrm{M}$ (anaerobic) or $100 \mu \mathrm{M}$ (aerobic) the inhibition reached significance ( $\mathrm{p}$ < 0.05). $\mathrm{n}=3$ in duplicate. (B) Reaction of HNO with ferric catalase to give the ferrous-nitrosyl complex. Representative reaction shown, time from first to last scan was 15 minutes. 


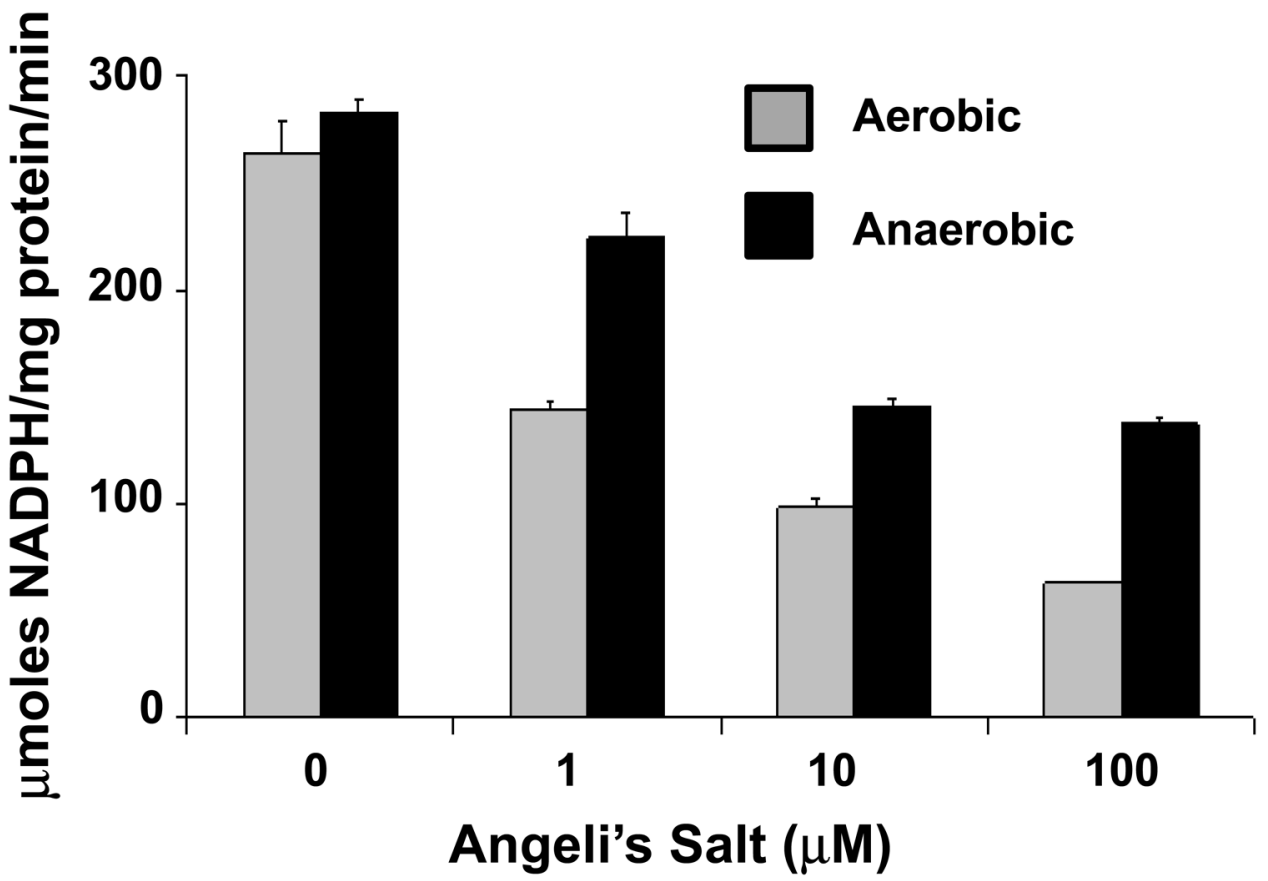

Figure 2.

Effect of HNO on purified GPx activity. Bars indicate means \pm standard deviation. Above 1 $\mu \mathrm{M}$ (anaerobic) or $10 \mu \mathrm{M}$ (aerobic) the inhibition reached significance $(\mathrm{p}<0.05) . \mathrm{n}=3$ in duplicate. 


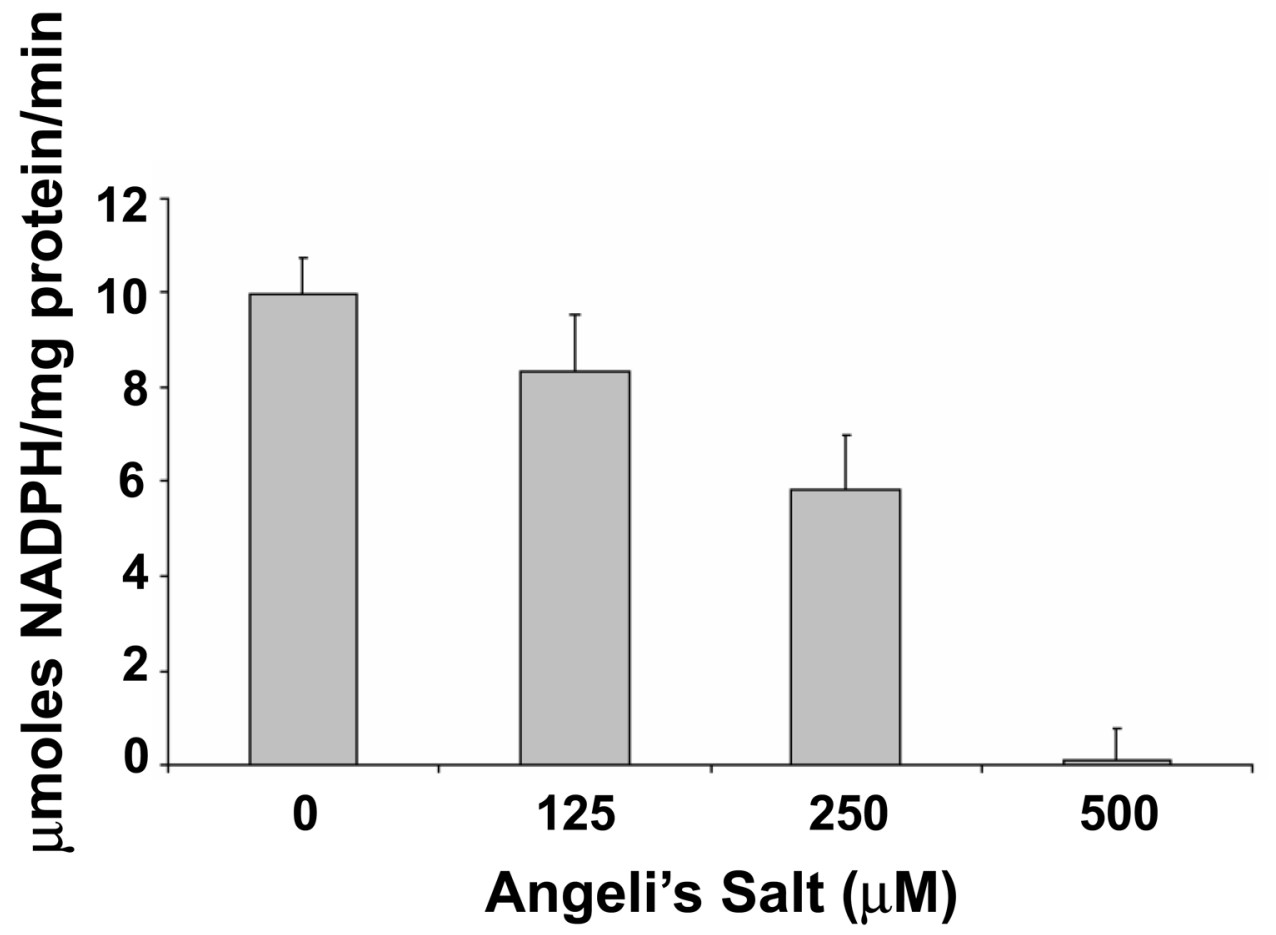

Figure 3.

Effect of HNO on GPx activity in lysates from HNO-treated cells. Bars indicate means \pm standard deviation. At 250 and $500 \mu \mathrm{M}$ the inhibition reached significance $(\mathrm{p}<0.05)$. $\mathrm{n}=3$ in duplicate. 
A

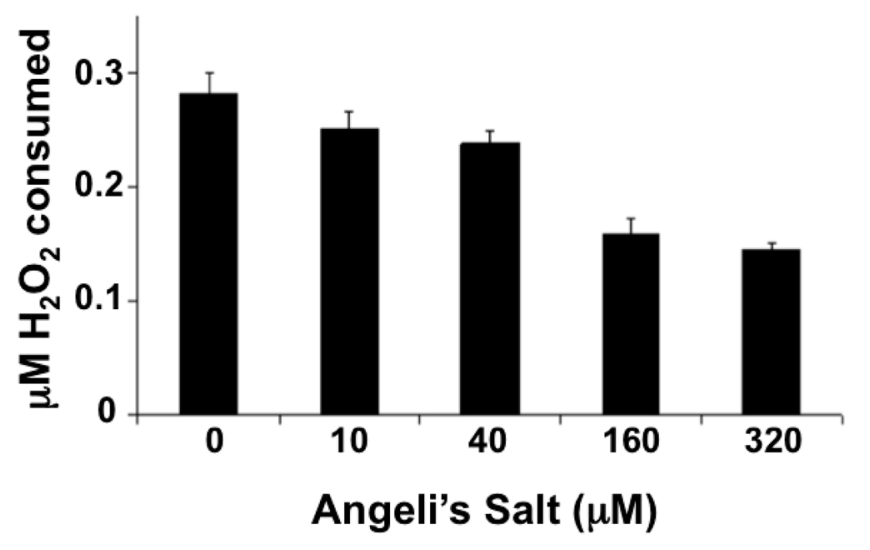

B

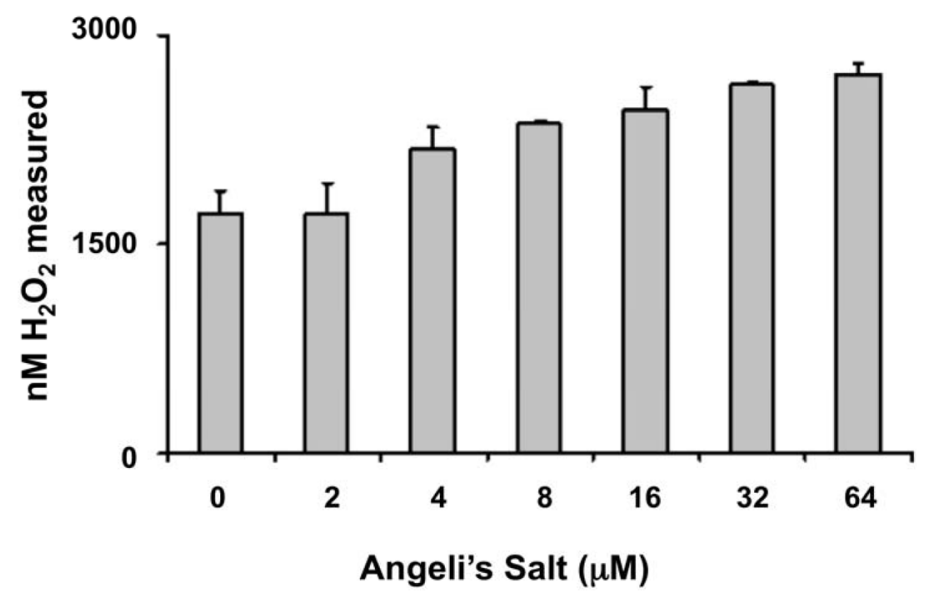

Figure 4.

(A) The effect of HNO (Angeli's salt) on the ability of macrophages to degrade exogenously added $\mathrm{H}_{2} \mathrm{O}_{2}$. Bars indicate means \pm standard deviation. At 160 and $320 \mu \mathrm{M}$ the inhibition reached significance ( $\mathrm{p}<0.05) . \mathrm{n}=3$ in duplicate. (B) The effect of HNO (Angeli's salt) on the extracellular levels of $\mathrm{H}_{2} \mathrm{O}_{2}$ generated endogenously by PMA stimulation. Bars indicate means \pm standard deviation. 


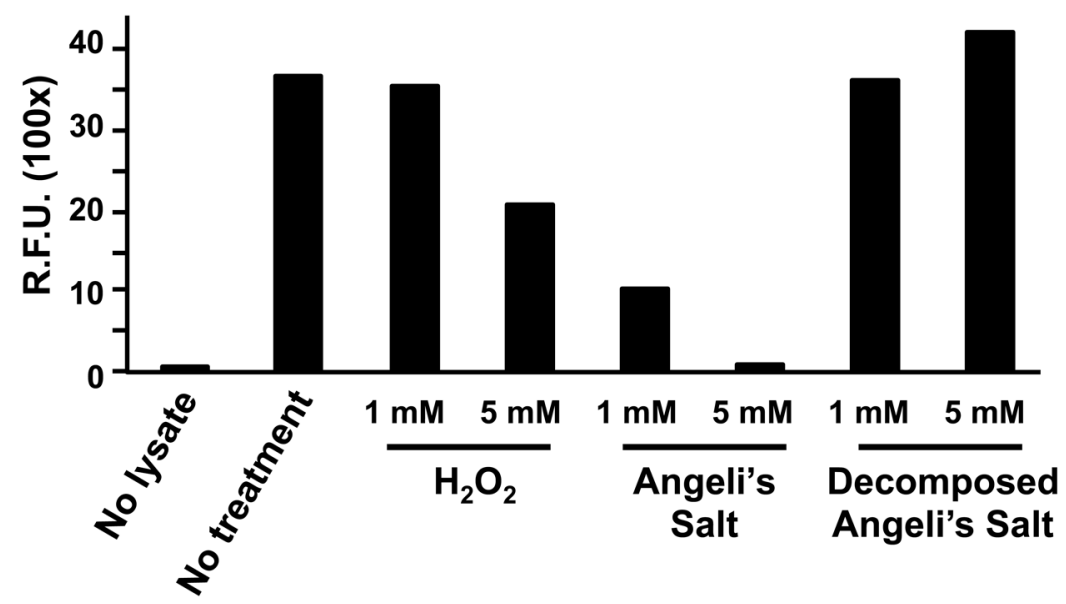

Figure 5.

Comparison of the effect of $\mathrm{H}_{2} \mathrm{O}_{2}$ and $\mathrm{HNO}$ on $\mathrm{CD} 45$ phosphatase activity. Jurkat T cells were exposed to $\mathrm{H}_{2} \mathrm{O}_{2}$, Angeli's Salt, or decomposed Angeli's Salt at the indicated concentrations for $15 \mathrm{~min}$. Cells were then lysed and the CD45 isolated. Samples were then assayed for phosphatase activity using FDP as a substrate. Data shown is representative of at least 3 separate experiments. 
A

Angeli's Salt (HNO Donor)

B

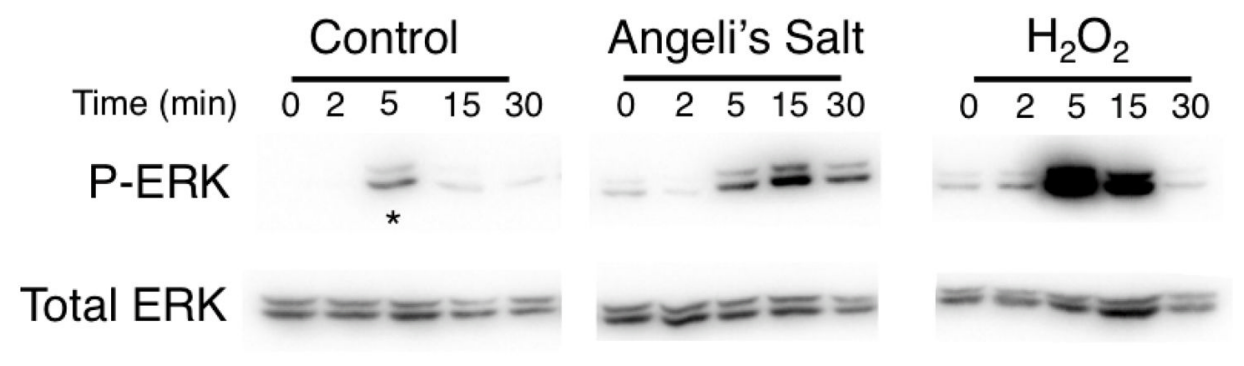

Figure 6.

(A) Serial dilutions were performed with Angeli's salt $\left(\mathrm{Na}_{2} \mathrm{~N}_{2} \mathrm{O}_{3}\right)$ and $\mathrm{H}_{2} \mathrm{O}_{2}$ and then used to stimulate Jurkat T cells. Cells were lysed at $15 \mathrm{~min}$. for Angeli's Salt and $5 \mathrm{~min}$. for $\mathrm{H}_{2} \mathrm{O}_{2}$. Samples were separated by SDS-PAGE and then transferred to nitrocellulose for immunoblotting with anti-P-ERK or anti-ERK antibodies. The samples were then visualized using the appropriate secondary antibody and chemiluminescent substrate. (B) Jurkat $\mathrm{T}$ cells were exposed to decomposed Angeli's Salt (1 mM, control), Angeli's Salt ( $1 \mathrm{mM})$, or $\mathrm{H}_{2} \mathrm{O}_{2}$ $(1 \mathrm{mM})$ and then lysed at varying time points. SDS-PAGE was performed on the samples and then transferred to nitrocellulose for immunoblotting with an anti-P-ERK or anti-ERK antibody. The samples were then visualized using the appropriate secondary antibody and chemiluminescent substrate. *Phosphorylation of ERK in the control was determined to be from nitrite, a byproduct of decomposed Angeli's salt. Data shown is representative of at least 3 separate experiments. 


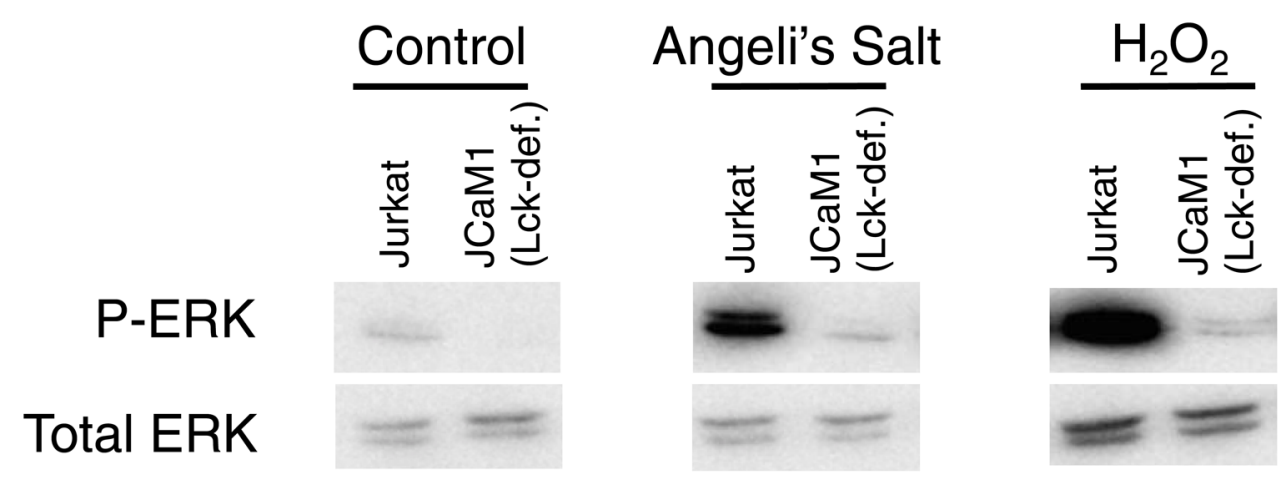

Figure 7.

Normal Jurkat T cells and Lck-deficient JCaM1 cells were left untreated, treated with Angeli's Salt (HNO donor, $1 \mathrm{mM})$, or hydrogen peroxide $\left(\mathrm{H}_{2} \mathrm{O}_{2}, 1 \mathrm{mM}\right)$. Cells were lysed at 5 min. for $\mathrm{H}_{2} \mathrm{O}_{2}$ and at $15 \mathrm{~min}$. for Angeli's Salt. Samples were then analyzed using SDSPAGE followed by immunoblotting with anti-P-ERK and total ERK antibodies. Lckdeficient cells show a decreased response to $\mathrm{H}_{2} \mathrm{O}_{2}$ as well as HNO. Data shown is representative of at least 3 separate experiments. 

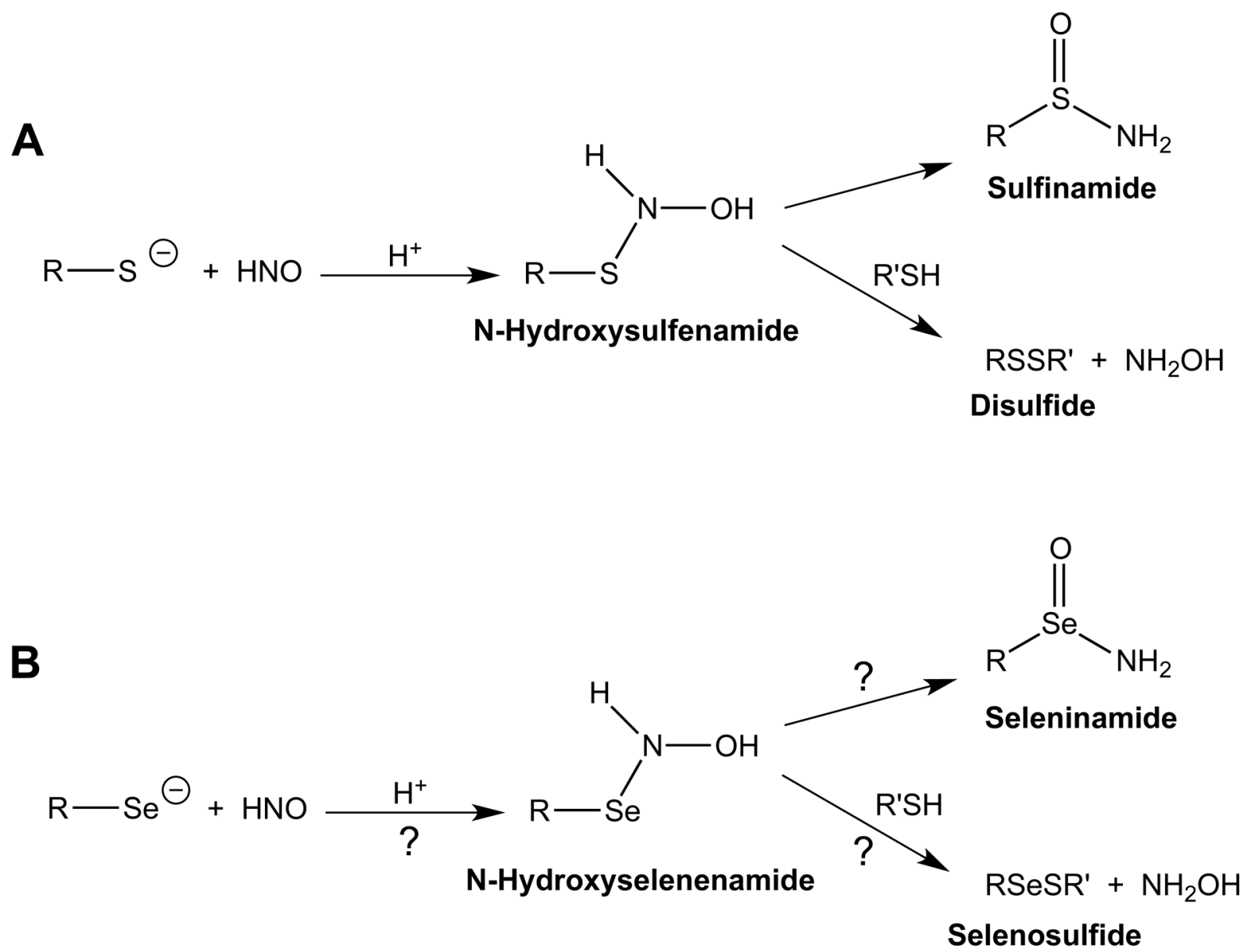

Figure 8.

(A) The reaction of thiols with $\mathrm{HNO}$ and (B) the comparison of the reaction of selenides with HNO. 


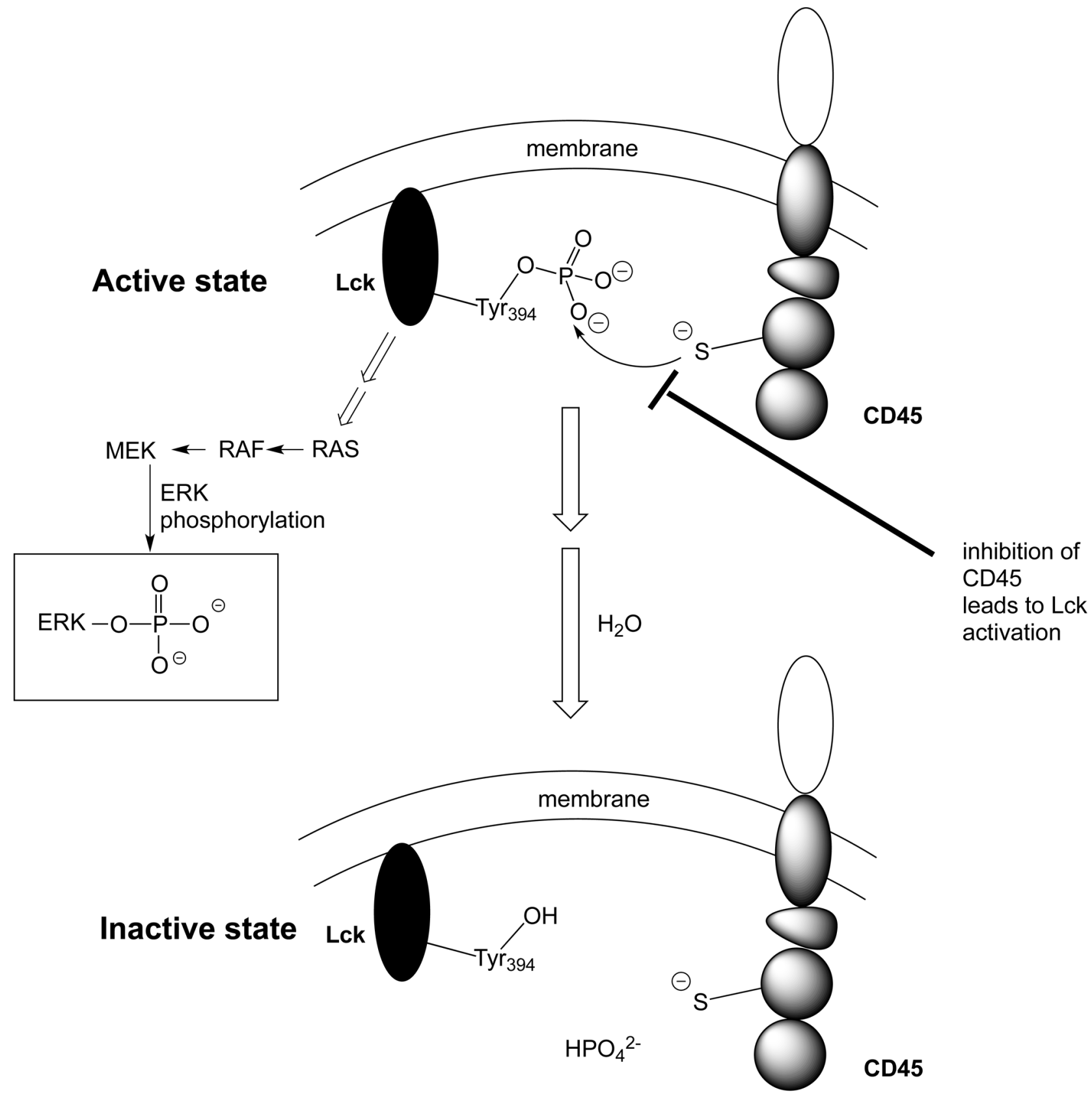

Figure 9.

Effect of CD45 on the kinase activity of Lck. CD45 can dephosphorylate the positive regulatory Tyr-394 site leading to inactivation of Lck activity. Thus, inhibition of CD45 leads to Lck activation, which initiates a cascade of events leading to ERK phosphorylation. 